\title{
Endometriosis and Angiogenic Factors
}

\author{
P. G. Artini, M. Ruggiero, F. Papini, G. Simi, V. Cela and A. R. Genazzani \\ Department of Gynecology and Obstetrics University of Pisa, Pisa, \\ Italy
}

\section{Introduction}

Little is known about the pathogenesis of endometriosis. The prevailing hypothesis is that following retrograde menstruation, uterine endometrial tissue attaches, invades the peritoneal surface, and becomes vascularized.

The development of new blood vessels represents a crucial step during the establishment of endometriosis because endometriotic implants require neovascularization to guarantee oxygen and essential nutrient supply (Groothuis et al., 2005; McLaren, 2000). The interaction between the ectopic endometrium and the peritoneal tissue is a prerequisite for the induction of angiogenesis and the maintenance of endometriosis

At least, three processes appear to be critical to the establishment of endometriosis, according to the implantation theory: invasiveness, tissue remodeling and interactions between the ectopic endometrium and the surrounding peritoneal tissues (Giudice et al., 2008).

The establishment of endometriotic lesions needs a cascade of neoangiogenic factor, like the vasculatr endothelial factor, cytokines and metalloproteinases: this complex interrelation between factors permit sprouting of capillaries from pre-existing vessels and the subsequent supply for the development of ectopic implants (Hyder and Stancel, 1999).

\section{Vascular endothelial growth factors family}

\subsection{Vascular Endothelial Growth Factor(VEGF)}

\subsubsection{VEGF family and its receptors}

Vascular endothelial growth factors are important signaling proteins involved in both vasculogenesis (the de novo formation of the embryonic circulatory system) and angiogenesis (the growth of blood vessels from pre-existing vasculature). VEGF family comprises seven members: VEGF-A, VEGF-B, VEGF-C, VEGF-D, VEGF-E, VEGF-F, and PIGF. All members have a common VEGF homology domain. This core region is composed of a cystine knot motif, with eight invariant cysteine residues involved in inter- and intramolecular disulfide bonds at one end of a conserved central four-stranded-sheet within each monomer, which dimerize in an antiparallel, side-by-side orientation (Neufeld G, wt al 1999).

The human VEGF gene (VEGFA, OMIM 192240) is located on chromosome 6p12 (Zhao Z, et al 2008). 
Vascular endothelial growth factor (VEGF) is one of the most potent and specific angiogenic factors. When VEGF binds to its targeted receptor, the VEGF receptor activation leads to a rapid increase in intracellular $\mathrm{Ca} 2+$ and inositol triphosphate concentrations in endothelial cells. The basic physiological function of VEGF is to induce angiogenesis, which allows the endometrium to repair itself following menstruation. It also modulates the characteristics of the newly formed vessels by controlling the microvascular permeability and permitting the formation of a fibrin matrix for endothelial cell migration and proliferation. This modulation may be responsible for local endometrial edema, which helps prepare the endometrium for embryo implantation. In endometriosis patients, VEGF is localized in the epithelium of endometriotic implants, particularly in hemorrhagic red implants. Moreover, the concentration of VEGF is increased in the PF of endometriosis patients. The exact cellular sources of VEGF in PF have not yet been precisely defined. Although evidence suggests that endometriotic lesions themselves produce this factor, activated peritoneal macrophages also can synthesize and secrete VEGF.

In women, physiological neoangiogensis is presented during the female reproductive cycle. VEGF-A is important in luteal angiogenesis. VEGF-A mRNA or protein is detectable in the granulosa cells of primordial and primary follicles, as they progressively become localized to the granulosa surrounding the oocyte and theca cells of the preovulatory follicle. After ovulation, VEGF-A mRNA and protein expression are observed in granulosa-derived luteal cells. VEGF-A expression in the corpus luteum appears highest early in the luteal phase and declines after the mid-luteal phase, with little or no expression in the late corpus luteum (Fraser HM, et al 2000). Gonadotrophic hormones, particularly luteinizing hormone (LH), appear to be major regulators of angiogenesis in the ovary (Hyder SM. Et al, 1999). The LHstimulated luteinization of granulosa cells at the time of ovulation is associated with enhanced VEGF-A expression.

When VEGF is overexpressed, it can contribute to disease. Three VEGF tyrosine kinase receptors have been identified: The fms-like tyrosine kinase Flt-1 (VEGFR-1/Flt-1), the kinase domain region, also referred to as fetal liver kinase (VEGFR-2/KDR/Flk-1), and Flt-4 (VEGFR-3). Each receptor has seven immunoglobulinlike domains in the extracellular domain, a single transmembrane region, and a consensus tyrosine kinase sequence interrupted by a kinase insert domain (Ortega $\mathrm{N}$ et al, 1999). Binding its receptors R1, VEGF regulates development of tubular capillaries; binding R2 receptor, it promotes mesodermic cells differentiation into endothelial cells. In vivo and in vitro experiments indicate that steroid hormones, hypoxia and nitric oxide are potent inducers of vascular endothelial growth factor gene expression by enhancing hypoxia inducible factor 1-a activity and by the activation of the AKT/ protein kinase B pathway (Kimura H, et al 2006).

\subsubsection{VEGF role in endometriosis}

Although the aetiology of endometriosis is unknown, it is generally accepted that the condition is a result of the implantation of exfoliated endometrium, deposited in the peritoneal cavity following retrograde menstruation (Sampson J 1927). When the exfoliated endometrium enters the peritoneal cavity and becomes attached to the mesothelial layer through attachment proteins like the cadherins, a process of angiogenesis is essential for further implantation and the development of peritoneal endometriosis (Nisolle $\mathrm{M}$ et al 1993). Angiogenesis is a fundamental process by which new blood vessels are formed and is considered as a major process in the pathogenesis of endometriosis. It is dependent on 
soluble factors released from cells. Many factors are involved in this complex mechanism, including FGF-a, FGF- b, PD-ECGF and VEGF, stimulate vascular endothelial cell growth in vitro and angiogenesis in vivo (Gordon J. Et al, 1995).

The development and maintenance of endometriosis is dependent on the recruitment of blood vessels to the endometriotic lesions from pre-existing ones to guarantee oxygen and essential nutrient supply. It has been shown that those endometriotic lesions recruit blood vessels by inducing angiogenesis. In a rat model, analyses of the assessed microvessel density demonstrated that angiogenesis is higher in ectopic endometriotic lesions compared with the eutopic endometrium (Machado DE et al, 2010).

Promoting angiogenesis, VEGF is involved in the etiology but also in the maintenance of peritoneal endometriosis. The endometrial tissue that has been migrated into the peritoneal space develops different angiogenic properties and invasive patterns, which could have a role in the implantation in the peritoneum of the pelvic cavity. It is likely that the action of VEGF in the implant of endometrial ectopic cells is to promote the differentiation of mesodermic cells into endothelial cells and to regulate the tubular capillary formation (Di Carlo C. Et al 2009).

VEGF-A is localized predominantly in the glandular epithelium of endometriosis lesions. Peritoneal fluid concentrations of VEGF have been demonstrated to be significantly higher in women with endometriosis than in the control patient and a positive correlation between the severity of endometriosis and the concentrations of VEGF in peritoneal fluid has been observed. Peritoneal fluid itself induced higher expression of the protein participating in the establishment and persistence of peritoneal endometriosis (Fasciani G. Et al, 2000).

In patients with endometriosis, high concentrations of VEGF in cystic and peritoneal fluids may be ascribed to a state of inflammation, where macrophages, which are the main source of this growth factor, play a central role.

It has been shown that cytokines released from immune cells play an important role in the pathogenesis of endometriosis, and many of these cytokines possess angiogenic activity. Pelvic implants and peritoneal fluid macrophages are the most likely source of VEGF-A in peritoneal fluid. McLaren (McLaren J, et al 2006) showed that peritoneal fluid macrophages express receptors for steroid hormones and secrete VEGF-A in response to ovarian steroids. The VEGF receptors VEGFR-1 and VEGFR-2 were also detected, suggesting an autocrine regulation. Peritoneal macrophages and activated lymphocytes seem to play an integral role in the secretion of proinflammatory/proangiogenic cytokines resulting in upregulation of VEGF from infiltrating neutrophils and macrophages (Machado DE et al, 2010).

Ovarian endometriotic cysts also over express VEGF in their cystic fluid with respect to follicular and serous cysts and to a similar degree as ovarian cystadenocarcinoma and a negative or positive correlation of VEGF expression has been reported with cyst diameter.

In ovary the process of angiogenesis is characterized by the existence of complex interrelations between the cell components of the ovarian cyst: diffuse VEGF expression in epithelial cells was associated with larger cysts; high VEGF expression in capsular fibroblast was associated with bilateral cysts; and expression of VEGF was found to be related in epithelial cells, capsular fibroblast and vessels, suggesting that neoangiogenesis might especially affect the outer cell cyst wall, thus contributing to cyst growth.( Goteri G. et al, 
2004). The inner layers of cysts are characterized by high microvessel density but low expression of VEGF, whereas in the outer fibrosclerotic capsule, the vessels were less abundant, but Had a higher expression of VEGF and survive, thus activated to proliferate and protected from programmed cells death. Angiogenesis mediated by VEGF in the outer capsule contributed to the cyst growth and to the fibrosing process of adhesion (Goteri G. et al 2010). Antiangiogenetic drugs could act on the capsular vasculature and block the growth of ovarian cyst. The high VEGF levels could provoke an increase in the subperitoneal vascular network and facilitate implantation and viability of endometrial cells in the retroperitoneal space. Concerning sVEGFR-1, the highest levels of this protein were found in peritoneal fluids and cystic fluids of endometriosis patients with respect to both benign and malignant serous cysts. The soluble form of VEGFR-1, as already stated, should function as a modulator of VEGF's angiogenic activity. For this reason, it seems that sVEGFR-1 is secreted in proportionate amounts as VEGF itself. In benign cyst and peritoneal fluids, VEGF and sVEGFR-1 concentrations are proportionately low, while in endometriosis cyst and peritoneal fluids, VEGF and its soluble receptor are both expressed in much higher concentrations. Endothelial sVEGFR-1 is also known to be up-regulated by its ligand, VEGF$\mathrm{A}$, and the high levels of VEGF-A found in endometriomata compared with cystadenomas are likely to further contribute to up-regulation of sVEGFR-1. On the other hand, in patients affected by cystadenocarcinomas, there was discordance between the levels of VEGF and the levels of sVEGFR-1 in both cyst and peritoneal fluids. In fact, in malignant processes there seems to be an imbalance between pro-angiogenetic factors, represented by VEGF, and antiangiogenetic factors, represented by sVEGFR-1, leading to a disordered and exaggerated formation of blood vessels (Artini PG et al, 2008).

The microenvironment of endometriosis is a locale of important secretion of angiogenic factors that play a key role in the establishment and maintenance of endometriotic lesions, and suggest that the balance of these local pro-antiangiogenic factors and cytokines may determine whether endometriotic lesions develop and grow.

\subsubsection{Genetic polymorphisms of VEGF genes}

An important aspect of the correlation between endometriosis and VEGF, also for possible future therapeutic application is that the polymorphisms in vascular endothelial growth factor gene are associated with the risk of familial endometriosis. The human VEGF gene (VEGFA, OMIM 192240) is located on chromosome 6p12 (Zhao Z, et al 2008). VEGF messenger ribonucleic acid and protein were significantly higher in women with endometriosis, which supported a key role for VEGF in the pathological angiogenesis in endometriosis (Gilabert-Estelles J, 2007). In particular several transcription factor-binding sites are found in the VEGF $5^{\prime}$-untranslated region and variation within the region increases the transcriptional activity. A single family in two generations with four members who have histologically proven endometriosis showed that the circulating levels of VEGF were higher than the healthy control group, indicating a role for VEGF in disease susceptibility (Simpson JL et al 2003). In Chinese patients, the T allele of the VEGF gene -60 $\mathrm{T} / \mathrm{C}$ (rs833061) polymorphism was associated with a higher risk of endometriosis. Study of the VEGF +405 G/C (rs2010963) polymorphism in a Korean population showed that the SNP was associated with the risk of advanced stage endometriosis. The analysis of both SNPs in an Indian population identified a haplotype associated with endometriosis In addition, the analysis of VEGF $-460 \mathrm{~T} / \mathrm{C}(\mathrm{rs} 833061),+405 \mathrm{G} / \mathrm{C}(\mathrm{rs} 2010963)$ and $+936 \mathrm{C} / \mathrm{T}$ 
(rs3025039) polymorphisms in 147 endometriosis cases and 181 controls found a positive association between stages III-IV disease and the VEGF $+936 \mathrm{~T}$ allele in a Japanese population. (Zhao Z, et al 2008). The first reported study in a Caucasian population of +405 G/C (rs2010963) in 203 Italian women affected with endometriosis and 140 controls reported a weak association of the $C$ allele with endometriosis (Gentilini D et al, 2008).

\subsubsection{Therapeutical approach}

Therapy of endometriosis consists of surgical removal of implants or medical treatment such as analogues of Gonadotrophin releasing hormone or oral contraceptive or progestins. This therapeutic approach has been shown to be of limited benefit so new approaches need to be developed. Considering the importance of angiogenesis in developing and maintaining disease, and the role of vascular endothelial growth factor, anti-angiogenetic drugs could be very important.

Romidepsin, the Histone deacetylase (HDC) inhibitor, modulates the expression of a variety of genes by alteriting gormatin structure. It has been recently shown to inhibit proliferation and activate apoptosis in human epithelial endometriotic cells. In particle Imesch demonstrated that his epigenetically acting drug inhibits VEGF transcription at low nanomolar concentration with high efficency. It works at the transcriptional level down regulated VEGF expression. Romidepsin reduced the level of HIF-a protein, indicating that VEGF mRNA expression may be related to the reduction of HIF- $\alpha$ protein levels. The issue of whether VEGF transcription is the primary target of romidepsin or if it acts preventing deacytalation of HIF-a, must still be solved. However Romidepsin, acting at a transcriptional level, could be more effective than other angiogenetic drugs, which inhibit the VEGF active form in targeting angiogenesis, and it can be considered a novel therapeutic candidate to counter endometriosis (Imesch P et al, 2011).

Gonadotrophin- releasing hormone agonist (GnHRa I) have been applied with success, in the treatment of endometriosis combined with the laparoscopic surgery. It leads to a reduction of ovarian hormone levels, to atrophy of endometriotic implants and it has antiproliferation and apoptotic effects. It reduce VEGF expression and it has been seen that after GnRHa treatment the concentration in peritoneal fluid of VEGF are significantly lower New molecule GnRHa II has been studied. Fengying et al demonstarted that this molecule can dose-dependently reduce VEGF protein secreted by ectopic and eutopic endometrial stromal cells cultured in vitro, and the inhibition effect is stronger than that of GnRHa I. GnRH II may reduce the secretion also of immune factors such as interleukin-8 and cyclooxigenase 2 relating to the incidence of endometriosis, suggesting for a antiproliferation and anti-inflammatory effect on endometrial cells (Fengying, $\mathrm{H}$ et al 2010).

Yilmaz showed (Yilmaz B et al, 2010.) the effect of metformin of endometriosis implants for his antioxidant characteristics and the beneficial effects on VEGF, and matrix metalloproteinases. In particular it reduces endometriotic implants in rats reducing VEGF levels.

Molecular therapies have been proposed as a treatment alternative for recurrent endometriosis. The use of concitionally replicative adenovirus (CRADs) has been explored for the therapy of disease. In particular Adenovirus constructed with the VEGF promoter controlling the expression of a marker gene have been evaluated in vitro culture of endometriotic cells. AdVEGFE1 replicates in a short-term culture of purified ectopic 
endometriosis cells. The virus induces apoptosis in endometriotic cells in vitro (Rein DT. Et al, 2010). Ad VEGFE1 allowed specific replication and efficient killing of endometriotic cells.

Another approach, which has been recently been published (Essam -Eldin R et al, 2008) is the transfection of endometriotic cells by dominant negative estrogen receptor gene via $\mathrm{Ad}$ vector. Dominant negative mutants of the estrogen receptor are altered estrogen receptors forms that are unable to activate transcription of estrogen-responsive genes when estradiol binds them, resulting in decreased cell proliferation and increased apoptosis.

\subsection{Endocrine Gland derived Vascular Endothelial Growth Factor (EG-VEGF)}

Human endocrine gland derived vascular endothelial growth factor is a secreted angiogenetic mitogen growth factor expressed in the steroidogenic glands, ovary, testis, adrenal and placenta. It induces proliferation, migration and fenestration (formation of membrane discontinue) in capillary endothelial cells derived from endocrine glands. Human EG-VEGF is a $9.6 \mathrm{kDa}$ protein consisting of 86 amino acid residues. Endocrine gland-derived VEGF (EG_VEGF) belongs to the prokineticin family. It is also known as prokineticn 1 (PK1). Although EG- VEGF is structurally distinct from VEGF, they induce similar angiogenic response in the ovary. The EG- VEGF acts through G-protein couplesd receptors, pkr1.

EG-VEGF was found to be expressed in non-endocrine tissues including endometrium: in human, it is highly expressed during the secretory phase of the menstrual cycle, when angiogenesis occurs. Lee et al evaluated the expression of EG-VEGF and its receptors in eutopic and ectopic endometrial tissues. A significant increase in molecule expression was found in the stromal cells of ectopic endometrium. It is possible that the stromal cells may synthesize EG-VEGF or that it is synthesize in the epithelial cells but is accumulated in the extracellular matrix of stroma. The endocrine gland-vascular endothelial growth factor, through its heparin- binding domain can, as VEGF, accumulated in the extracellular matrix (Lee K et al, 2010).

\section{Cytokynes (IL-1, IL-6, IL-8, TNF- a)}

Cytokines are small cell-signaling protein molecules that are secreted by several cells types and are a category of signaling molecules used extensively in intercellular communication. Cytokines can be classified as proteins, peptides, or glycoproteins; the term "cytokine" encompasses a large and diverse family of regulators produced throughout the body by cells of diverse embryological origin (Gilman et al., 2001). Virtually all nucleated cells, but especially endo/epithelial cells and resident macrophages (many near the interface with the external environment) are potent producers of IL-1, IL-6, and TNF-a (Boyle, 2005) .Studies have reported elevated levels of several cytokines in the peritoneal fluid of women with endometriosis, thus implicating these proteins in the development and progression of endometriosis and endometriosis-associated infertility (Koninckx et al.,1998); (Harada et al.,2001); (Bedaiwy et al., 2003); (Kalu et al., 2007). Peritoneal fluid is derived from plasma transudate and ovarian exudates and in a small part from secretions of the mesothelial surface and tubal luminal fluid. Some studies suggest that the peritoneal fluid of women with endometriosis contains an increased number of activated macrophages and other immune cells that secrete various local products, such as growth factors and cytokines, which exert a paracrine action on endometriotic cells. (Harada et al., 2001) 


\subsection{Cytokines and pathogenesis of endometriosis}

Studies have shown the role of some cytokines in the implantation of ectopic endometrial tissue, and its progression and infiltration. In the implantation and growth of ectopic tissue, a primary role was attributed to several cytokines contained in the peritoneal fluid including interleukin IL-1,IL-6, IL-8, IL-12 and tumor necrosis factor-a (TNF-a) (Arici et al.,1996); (Iwabe et al., 1998); (Ho et al.,1997) Normally, peritoneal fluid contains leukocytes in concentrations of 0.5 to $2.03106 / \mathrm{mL}$, of which approximately $85 \%$ are macrophages (Syrop et al., 1987). Halme et al., (Halme et al.,1984) postulated that peritoneal macrophage activation may be a central contributor to the pathogenesis of endometriosis and activated macrophages in the peritoneal cavity of women with endometriosis (Vinatier et al., 1996) are potent producers of cytokines (Halme, 1989) ;( Fakih et al., 1987); (Rana et al., 1996). Thus, peritoneal fluid contains a rich cocktail of cytokines. Cytokines play a major role in the initiation, propagation, and regulation of immune and inflammatory responses. Immune cell activation results in a burst and cascade of inflammatory cytokines. These cytokines have pleiotropic and redundant activities that culminate in recruitment of numerous cell types to the site of inflammation (Harada et al, 2001). More, cytokines may regulate the actions of leukocytes in the peritoneal fluid or may act directly on ectopic endometrium, where they may play various roles in the pathogenesis and pathophysiology of endometriosis. Increased levels of cytokines in the peritoneal fluid of women with endometriosis may reflect increased synthesis of cytokines by peritoneal macrophages, lymphocytes, ectopic endometrial implants, or mesothelial cells of the peritoneum, all of which can produce cytokines (Tabibzadeh et al., 1989) ; (Betjes et al., 1993). The main source of cytokines is thought to be the macrophages, which originate in bone marrow, circulate as monocytes, and migrate to various body cavities. It seems that the cytokines playing the most important role in the endometriosis are : IL-1, IL-6, IL-8,IL-12, TNF- $a$.

- Interleukin-1 (IL1) is one of the major proinflammatory cytokine found in the peritoneal fluid of women with endometriosis (Mori et al., 1991); (Taketani et al., 1992); (Fakih et al., 1987). This multifunctional cytokine was shown to stimulate the production of angiogenic factors by ectopic endometrial cells and therefore play a role in ectopic endometrial cell growth (Lebovic et al., 2000). Other studies pointed to a possible role for IL1 in endometriosis-associated infertility (Fakih et al.,1987); (Sueldo et al.,1990). Both ectopic and eutopic endometrial cells of women with endometriosis display an increased sensitivity to IL1, which results in an enhanced production of angiogenic, growth, and proinflammatory factors (Lebovic et al., 2000); (Akoum et al., 1995); (Akoum et al.,2002).Some previous studies showed that the increased endometrial and endometriotic cell responsiveness to IL1 may in part be due to a deficiency in the expression of interleukin-1 receptor type II (IL1R2) revealed in eutopic and ectopic endometrial tissues (Akoum et al., 2001);(Kharfi et al.,2002). The soluble IL1R2 levels were found to be reduced in the peripheral blood of women with endometriosis, which may account for the activation of peripheral blood monocytes in them (Kharfi et al., 2002). More, the IL1R2 has no signaling properties in contrast to the functional signaling IL1R1, which mediates cell activation by IL1 (Bossu et al., 1995); (Dinarello 2004); (Colotta et al.,1993). However, the membrane form of this receptor and the soluble form, which is shed by proteolysis from the cell surface (Cui et al.,2003); (Orlando et al.,1997), bind to IL1 and with higher affinity to IL1b, which is the circulating and the preferential ligand for IL1R2, in particular for its soluble form (Bossu et al., 1995). This inhibits the interaction of 
IL1 with its functional receptor type I and, consequently, IL1-mediated cell activation (Bossu et al., 1995); (Colotta et al.,1993); (Subramaniam et al., 2004);(Symons et al, 1995). Akoum et al. (Akoum et al., 2008) showed an imbalance in IL1/soluble IL1R2 levels in women with endometriosis suffering from infertility and pelvic pain and a relationship with endometriosis initial stages and infertility. This is in keeping with other findings showing a reduced expression of IL1R2 in the eutopic endometrial tissue of women with endometriosis, particularly in those who were infertile, and provide evidence for a deficiency in the regulation of IL1 actions at the local peritoneal level in initial endometriosis stages, which may result in increased cell reactivity and contribute to endometriosis development and the manifestation of its clinical symptoms.

- Interleukin-6 (IL-6) is a pleiotropic cytokine that is produced by a variety of cell types, including monocytes, lymphocytes, fibroblasts, endothelial cells, and mesangial cells. It is said to mediate numerous physiological and pathogenic processes and acts on a wide variety of cells. IL-6 may also have important functions in reproductive physiology, including the regulation of ovarian steroid production, folliculogenesis and early events related to implantation. (Jacobs et al.,1992); (Akoum et al., 1996). Both eutopic and ectopic endometrium are known to produce IL-6 (Harada et al., 1997). Infact IL-6 belongs to the group of cytokines produced in increased amount by endometriotic cells both in basal and cytokine-stimulated conditions (Akoum et al., 1996), (Tsudo et al., 2000). IL-6 in turn is able to increase the secretion of several other cytokines and promotes the activation of immune cells (Iwabe et al., 2002).Examining eutopic endometrium from patients with endometriosis , it was found an increased basal- and IL-1b stimulated production of IL-6 compared with patients without endometriosis. This suggests that the endometrial cells of women who develop endometriosis may function differently from those in women who do not develop this condition. Endometrial stromal cells were considered the critical cells in endometrial attachment to the mesothelial surface of the peritoneum and that endometrial epithelial cells fail to attach to the mesothelium (Scott et al., 1953). It has also been suggested that cellular adhesion itself stimulates chemokine expression (Smith et al.,1997). More interestingly IL-6 family cytokines, such as IL-6, IL-11, leukemia inhibitory factor, and oncostatin M, were shown to be potent stimulators of aromatase expression in adipose stromal cells in culture (Zhao et al.,1995). Yoshioka et al. (Yoshioka et al.,1999) reported that IL-6 inhibits proliferation of endometrial stromal cells derived from the secretory phase but not from the proliferative phase. In contrast, negative regulation by IL-6 was not observed in the stromal cells of endometriotic tissues, suggesting that the biological characteristics of endometriotic cells differ from those of eutopic endometrial cells. Bedaiwy et al. (Bedaiwy et al., 2002) reported that serum IL- 6 and peritoneal fluid TNF- $a$, could be used to discriminate between patients with and without endometriosis with a high degree of sensitivity and specificity. On the other hand, other authors, such as Kalu (Kalu et al, 2007) have failed to confirm this. They did not find any significant differences in the concentration of IL-6 in the sera of women in the two groups and more, they try to explain this result, considering that the measurement of cytokine concentrations is complicated by the fact that they have very short half-lives and are never produced in isolation, but as a mixture which may have similar or opposing effects. So, it is possible that the circulating IL-6, IL-1 b, and TNF- $a$ found by some investigators may be non-functional or antagonized by anti-inflammatory cytokines or cytokine inhibitors. While this may also be true of peritoneal fluid cytokines, the presence of activated macrophages does suggest that at least some of the cytokines are functionally active. 
- Interleukin-8 (IL-8) is a potent angiogenic cytokine produced by mesothelial cells, macrophages, and endometrial and other cells. Its concentration in the peritoneal fluid of patients with red endometriosis is found to increase as the size and number of active lesions increase (Iwabe et al.,1998). It stimulates adhesion of endometrial stromal cells to extracellular matrix proteins, matrix metalloproteinase activity and endometrial stromal cell proliferation in a dose-dependent manner, all of which can help to promote the implantation and growth of ectopic endometrium (Garcia-Velasco et al.,1999); (Ryan et al.,1995); (American Society for Reproductive Medicine, 1997); (Harada et al.,1997); (Punnonen et al.,1996); (Jolicoeur et al., 1998); (Akoum et al.,2000); (Pizzo et al., 2002) ; (Arci et al., 1998).

- Arici et al. reported that IL-8 is produced in the human endometrium in vivo, mainly in glandular cells (Arici A, et al.,.) and that this interleukin induces proliferation of endometrial stromal cell as a potential autocrine growth factor (Arici et al., 1998). Iwabe et al. (Iwabe et al.,1998) also found that peritoneal fluid levels of IL-8 significantly enhanced proliferation of stromal cells derived from ovarian endometriomas. Expression of IL-8 receptor type A messenger RNA was detected in endometriotic stromal cells These results suggest that IL-8 may promote the progression of endometriosis.

- Tumor necrosis factor a (TNF- $\alpha$ is a cytokine involved in systemic inflammation and is a member of a group of cytokines that stimulate the acute phase reaction. The primary role of TNF is in the regulation of immune cells. TNF is able to induce apoptotic cell death, to induce inflammation and to inhibit tumorigenesis and viral replication. It is considered the most representative cytokine involved in the pathogenesis of endometriosis: a clear positive association between the content of TNF- $\alpha$ in peritoneal fluid and the severity of endometriosis has been demonstrated (Overton et al.,1996). Numerous studies indicate that both activated macrophages and the ectopic endometrium itself are responsible for the abnormal production of TNF- $\alpha$ in the peritoneal fluid and that this cytokine is involved in the proliferation of endometriotic stromal cells (Iwabe et al., 2000). It acts through both direct and indirect mechanisms, and by mediating the proliferative effect of IL-8 (Sakamoto $\mathrm{Y}$ et al., 2003 ). Moreover, gene and protein expression of IL-8 in the stromal cells of endometriotic tissues are up-regulated by TNF- a (Iwabe et al., 2000), and TNF- a stimulates the proliferation of the endometriotic stromal cells. This stimulatory effect of TNF- a was abolished by adding anti-TNF- $\alpha$ antibody or anti-IL- 8 antibody. Therefore, TNF- $\alpha$ may act on stromal cells by mediating the proliferative effects of IL-8. Expression of type I and type II receptors for TNF- a was observed in endometriotic stromal cells. This evidence suggests that TNF- $a$ action mediated by IL-8 may not only be an initiating factor that facilitates adhesion of endometrial cells to the peritoneum but may also contribute to development and progression of endometriosis. Thus, the differential response of endometrial cells to TNF- $\alpha$ in women with and without endometriosis may reflect differential regulation of TNF-receptor expression or signaling by this cytokine. Braun et al. (Braun et al., 2002) published data suggesting that in women without endometriosis, endometrial cells do not implant in ectopic locations because normal apoptotic mechanisms are activated by TNF- $\alpha$ through the TNFR1 receptor and because the proliferation enhancing effects of TNF- $a$ are inhibited by down-regulation of the TNFR2 receptor. Disruption or dysregulation of the normal, cyclical expression of these two TNF- a receptors on endometrium from women with endometriosis could create cells that can grow in the presence of high concentrations of TNF- a a possibility for which evidence is avalaible (Ding et al.,2000). Harada et al. (Harada et al., 1997) and Iwabe et al. (Iwabe et al.,1998) found that the extent of superficial red 
endometriotic lesions was related to increased levels of IL-6, IL-8, and TNF- $a$ in the peritoneal fluid. Red lesions, such as red flame-like lesions, gland-like lesions, and red vesicles, were classified as active lesions of endometriosis because angiogenesis is more pronounced in red lesions than in black or white lesions (Wiegerick et al.,1993) and because early red lesions invade extracellular matrix (Spuijbroek et al.,1992). Braun et al. (Braun et al., 2002) also suggested that ectopic growth of endometrial cells and the physiological consequences of that growth in women with endometriosis may be retarded by agents that block the effects of TNF- a. Presumably, this could be achieved by blocking TNF- a production (e.g., administration of pentoxifylline or ciprofloxacin) or by blocking the effects of TNF- a on target tissues (e.g., administration of etanercept). The attenuation of the proliferation-enhancing activity in peritoneal fluid from women with endometriosis by etanercept that the athors observed, and results in an animal model of endometriosis using a recombinant human TNF-binding protein (D'Antonio et al., 2000;), support this idea. Blocking the effects of TNF- a on target tissues might be especially appropriate in patients with extensive or intractable disease and might be useful in the postsurgical adjuvant setting to reduce the likelihood of recurrence. Given the potential of TNF- a to play a prominent role in both the etiology and the pathogenicity of endometriosis, studies of such treatment are warranted

- Interleukin-12 (IL-12) is naturally produced by dendritic cells ( Kaliński Pet al., 1997), macrophages and human B-lymphoblastoid cells in response to antigenic stimulation. It is known as a T cell-stimulating factor, which can stimulate the growth and function of $\mathrm{T}$ cells. It stimulates the production of interferon-gamma (IFN- $\gamma$ ) and tumor necrosis factor-alpha (TNF-a) from $\mathrm{T}$ and natural killer (NK) cells, and reduces IL-4 mediated suppression of IFN$\gamma$. It acts on $\mathrm{T}$ and NK cells, inducing cytokine production, enhancing NK cell cytotoxic activity, and finally favoring generation of Th1 cell response, (Kobayashi et al., 1989) ;(Wysocka et al., 1995) so it seems to play an important role, in the controll of the endometriosis. Harada et al., (Harada et al.,2001)demonstrated that the concentrations of IL12 in the peritoneal fluid are low, but detectable, regardless of the presence or absence of endometriosis (Zeyneloglu et al., 1998). Administration of IL-12 significantly prevented ectopic endometrial implantation in a murine model of endometriosis (Somigliana et al.,1999). A direct growth inhibitory effect on endometrial cells seems unlikely because endometrial cells do not express receptors for IL-12. A potential explanation for these results is that IL-12 enhances the growth and augments the cytolytic activity of both NK and T cells. These data support the idea that manipulation of cytokine activity in the peritoneal fluid is a novel management approach to controlling the establishment of endometriosis.

\subsection{Cytokines and endometriosis related to infertility}

Muscato et al. (Muscato et al., 1982) demonstrated that peritoneal macrophages phagocytized sperm in vitro and that macrophages from women with endometriosis were more active than those from women without the disease. Peritoneal fluid diffusing into the tubal and endometrial environment may affect sperm and their interaction with the oocyte. Studies showed that the peritoneal fluid of patients with endometriosis has detrimental effects on sperm function. Sperm motility (Curtis et al., 1993) ;(Drudy et al., 1994), acrosome reaction (Arumugam et al.,1994), gamete interaction (Coddington et al, 1992.), and ovum capture by tubal fimbriae (Suginami et al., 1988) have been studied. Aeby et al. (Aeby et al.,1996), using a penetration assay, showed that peritoneal fluid from patients with 
endometriosis impaired gamete interaction. In their study, the mean number of eggs penetrated by sperm mixed with peritoneal fluid from patients with endometriosis was significantly less than that observed in controls. These data suggest that substances in the peritoneal fluid of patients with endometriosis contribute to infertility by impairing sperm function. Peritoneal fluid from patients with endometriosis has frequently been shown to be toxic to the preimplantation embryo. A study demonstrated that medical treatment of endometriosis eliminated the embryotoxicity of the peritoneal fluid (Keenan et al.,1995). In this study, the levels of IL-1 and TNF- a were markedly reduced in the peritoneal fluid of women who had undergone medical treatment (danazol or intranasal buserelin for 4 to 6 months) of endometriosis. This finding supports the hypothesis that increased levels of cytokines in peritoneal fluid may be involved in the pathogenesis of endometriosisassociated infertility. One study demonstrated that the addition of human recombinant IL-6 to culture medium suppressed the rate of blastocyst formation of mouse embryos (Harada et al., 1997), suggesting that increased IL-6 in the peritoneal fluid of endometriosis patients may contribute to infertility by adversely affecting embryonic development. Moreover, other authors (Minici et al., 2008) showed that in endometriosis, the milieu surrounding the uterine cavity may be involved in impaired eutopic endometrial stromal cell decidualization, partially due to increased peritoneal levels of TNF- a. So they concluded that in endometriosis either intrinsic defects of endometrial stromal cell differentiation or the biochemical environment of the uterine cavity could concur to compromise the normal decidualization required for optimal implantation.

In conclusion, cytokines, which are produced by many cell types in peritoneal fluid, play a diverse role in constructing the peritoneal environment that induces the development and progression of endometriosis and endometriosis-associated infertility.

Intense basic research into the specific role of these cells and soluble factors may improve our understanding of endometriosis and result in novel therapies for endometriosis.

\section{Transforming growth factor beta (TGF-ß)}

Transforming growth factor beta (TGF- $\beta$ ) is a protein that controls proliferation, cellular differentiation and other functions in most cells. TGF- $\beta$ is a secreted protein that exists in at least five isoforms called TGF- $\beta 1$, TGF- $B 2$ and TGF- $B 3$. It was also the original name for TGF- $\beta 1$, which was the founding member of this family. TGF-beta acts as an antiproliferative factor in normal epithelial cells and at early stages of oncogenesis. Some cells that secrete TGF- $\beta$ also have receptors for TGF- $\beta$. This is known as autocrine signalling. Cancerous cells increase their production of TGF- $\beta$, which also acts on surrounding cells.Oosterlynck et al. (Oosterlynck et al.,1994) found increased TGF-b activity in the peritoneal fluid of women with endometriosis. Transforming growth factor-b may be a cytokine that inhibits NK activity in the peritoneal fluid of women with endometriosis (Oosterlynck et al.,1994). It may play a major role in the biological processes leading to establishment and maintenance of endometriosis., in fact TGF- $B$ is implicated in the gene expression, cell motility, proliferation, apoptosis, differentiation, immune responses and tumorigenesis (Derynck et al., 2001). TGF-b is abundantly and differentially expressed in the endometrium and is secreted by endometrial cells and macrophages into the uterine fluid where interaction with the preimplantation embryo is suspected (Jones et al., 2006). 
Secretion of TGF-b into peritoneal fluid of women suffering from endometriosis suggests that they may be crucial in establishment and/or maintenance of endometriosis. Omwandho et al., showed that all TGF- $\beta$ and their high-affinity receptors were stagespecifically expressed in the human endometrium with highest levels around menstruation . Many researchers have reported staining of TGF-b1 and 3 in stromal and glandular cells (Chegini et al., 1994); (Gold et al., 1994) ; (Johnson et al., 2005) ; (Komiyama et al., 2007); (Gaide Chevronnay et al., 2008) and for TGF-b1 also in nerve fibres (Tamburro et al., 2003) and inflammatory cells specially in macrophages (Chegini et al., 1994); (Tamura et al., 1999); (Komiyama et al., 2007). TGF- B 2 is more strongly expressed in stromal compared with glandular cells (Gold et al., 1994); (Bruner et al., 1995); (Gaide Chevronnay et al., 2008), although opposite staining intensity has been reported (Chegini et al., 1994). Localization of TbRII and RI was observed in both cellular compartments of the endometrium (Chegini et al., 1994; (Gaide Chevronnay et al., 2008) with stronger expression of TbRII than TbRI (Gaide Chevronnay et al., 2008) suggesting that TbRI might be a limiting factor for signal transduction in the endometrium or during endometriosis. TGF-b1 was found in the stromal cells (Johnson et al., 2005) and expression increased in the epithelial cells of endometriotic cysts (Tamura et al., 1999) and endometriotic nerve fibers (Tamburro et al., 2003). The TGF-b signal transducers Smad3, pSmad3, Smad4 (SMADs are intracellular proteins that transduce extracellular signals from TGF beta ligands to the nucleus where they activate downstream TGF- $B$ gene transcription) and the inhibitory Smad7 proteins were also observed in the endometrial stromal and epithelial cells (Luo et al., 2003). These observation suggest a role of the TGF- $B \mathrm{~s}$ in the normal function of the human endometrium. In fact is well known that TGF- $\beta$ sprevent the breakdown of the endometrial tissue (Tabibzadeh, 2002). This assumption is based on the observation that Lefty-2/EBAF (endometrial bleeding associated factor), a member of the TGF-b family, is dramatically up-regulated during endometriosis (Kothapalli et al., 1997) and antagonized TGF- $\beta$ signaling by inhibiting phosphorylation of Smad2 downstream of the TbRI (Ulloa et al., 2001). That Lefty-2 was noticeably more abundant in patients with endometriosis who did not conceive compared with those who became pregnant, suggested a role in implantation (Tabibzadeh et al., 2000). More, it has been shown that TGF- $B$ 1also induces contractions of decidual stromal cells (Kimatrai et al., 2003) and inhibits motility of stromal endometrial cells (Nasu et al., 2005).It is important to show how TGF- $B$ 1stimulated DNA synthesis in epithelial cells at low concentrations, but inhibited DNA synthesis at higher concentrations in women with and without endometriosis (Meresman et al., 2003). Additional evidence showed that TGF- $B$ 1induces expression of FasL mRNA and protein in endometrial stromal cells (Garci-Velasco et al., 1999), possibly preventing apoptosis during transit to the peritoneal cavity. Another very important analysis showed that TGF- $\mathbb{B}$ 1represses the immune system (Shull et al., 1992) and the escape from immune surveillance is also important for adhesion of endometriotic cells in the peritoneum. Finally TGF- Bs participate in the initiation of menstruation via vasoconstriction, in menstrual tissue repair and in endometriosis. In a classic experiment, Luo et al. (2003b) demonstrated that the pretreatment with a GnRH antaonist resulted in further suppression of Smad3 in endometrial stromal cells but co-treatment with GnRH and TGF- $§$ 1or pretreatment with TbRII antisense partially inhibited TGF- $§ 1$-activated Smad3. Taken collectively, these observations suggest that $\mathrm{GnRH}$ may prevent endometriosis by altering expression and activation of Smads and interrupting TGF- $₫$ receptor signaling. 


\section{Plasminogen activator (UPA) and matrix metalloproteinase systems (MMS)}

\subsection{Plasminogen activator system (PA)}

The PA system includes a wide cluster of proteolytic enzymes for plasmin generation. Plasminogen is activated to plasmin by two types of activators, urokinase-type PA (uPA) and tissue- type PA (tPA). Whereas tPA is involved in the role in the control of intravascular fibrin degradation, uPA is mainly implicated in cellular proteolysis and migration. The activity of the PAs is regulated by specific PA inhibitors (PAIs). (Kruithof et al., 1995; Grancha et al., 1996; Heeb et al., 1987).

The PA system and its specific plasminogen activator inhibitors (PAIs) exert physiological and pathophysiological functions such as fibrinolysis, tissue remodelling and tumor invasion, signal transduction, cell adherence and cell migration (Harbeck et al., 2001).

Fernández-Shaw et al., firstly reported high levels of urokinase and plasminogen in ectopic endometrium as a more invasive nature of the endometriotic implants in the peritoneal cavità (Fernández-Shawet al., 1995); afterwards, Sillem confirmed an altered activation of plasminogen in endometrium from women with endometriosis that could lead to a higher proteolytic potential of retrogradely menstruated endometrial fragments with consecutive development of endometriotic foci (Sillem et al., 1997).

In situ hybridization studies performed by Bruse et al. showed that uPA mRNA seems to be up-regulated in both endometriotic glands and endometrial stroma from women with endometriosis (Bruse et al., 2005).

Moreover, Lembessis and coworkers reported an increase in uPA mRNA expression in endometriotic lesions compared to eutopic endometrium (Lembessis et al. (2003).

Despite contrasting data in vitro culture model (Guan et al., 2002) ; recently, Cosin reported an increase in uPA antigenic levels in endometrium from women with endometriosis (Cosin et al., 2010)

In relation to PA levels in eutopic endometrium from women with endometriosis, it has been suggested that a higher concentration of uPA in the endometrium might result in endometrial fragments with a higher potential to degrade the extracellular matrix after the implantation at ectopic sites (Spuijbroek et al., 1992; Bruse et al., 1998, 2004; Kobayashi, 2000).

\subsection{Matrix metalloproteinase systems (MMPs)}

Matrix metalloproteinases (MMPs) are a class of zinc-dependent endopeptidases involved in extracellular matrix remodelling (Matrisian, 1992).

Members of this family share high level of structural analogy and are secreted by several cell types as zymogens. In relation to substrate preference and protein-domain considerations, MMP family members have been categorized into subgroups that include gelatinases, stromelysins, collagenases, membrane-type (MT)-MMPs and 'other MMPs'.

The activity of metalloproteinases is tightly regulated,as these molecules are potent proteolytic enzymes, at differente steps: transcriptional level (by cytokines, chemicals, and 
growth factors), post-translation modification and by a family of inhibitors: the tissue inhibitors of metalloproteinases or TIMPs (Matrisian, 1990).

Elevated cytokines may play a role in the establishment of ectopic endometrium in the peritoneal cavity by stimulating MMPs to remodel the mesothelial lining of the peritoneum thus allowing for tissue invasion.

MMPs are stimulated by cytokines and also by the protein Extracellular Matrix Metalloproteinase Inducer (EMMPRIN). Braundmeier et al., showed that IL-1beta stimulated MMP-1 protein secretion and mRNA levels in a time dependent manner $(\mathrm{P}<$ 0.05), MMP-2 mRNA in a time dependent manner and MMP-3 in a time and dose dependent manner. TNF-alpha stimulated MMP-1 and -3 protein secretion in a time dependent manner and stimulated MMP-1, -2 and -3 mRNA levels in a time dependent manner). Neither IL-1beta nor TNF-alpha treatment affected MMP-2 protein secretion. TGFbeta-1 inhibited MMP-1 and MMP-2 mRNAs at the highest treatment dose after $24 \mathrm{hr}$ but there was no effect on protein secretion. TGF-beta-1 exerted no effect on MMP-3 mRNA or protein secretion (Braundmeier et al., 2010).

MMPs have been implicated in the endometrial remodelling during the menstrual cycle with higher levels during menstrual and proliferative phases and decreased levels during the secretory phase (Salamonsen and Woolley, 1996);

Montly, in the absence of pregnancy, degradation of the ECM is a critical step in the initiation of tissue breakdown that leads to menstruation (Marbaix et al., 1996; Salamonsen and Woolley, 1996).

During the proliferative phase of the natural cycle, MMP-1, MMP-3 and MMP-9 are downregulated in the stroma (Hulboy et al., 1997), presumably to allow endometrial stable growth. The expression of MMPs then decline in the early secretory phase and then increase during the late secretory phase in anticipation of the next proliferative phase. These modification are related to serum progesterone levels, which has led to the suggestion that endometrial expression of MMPs is under gonadal steroid hormone control. Critically, MMP-9 expression is highest in the menstrual phase endometrium when tissue breakdown occurs.

Moreover, several repots suggest that these proteases are also involved in the ectopic invasion of endometriotic cells associated with endometriosis (Cox et al., 2001).

Deregulation of peritoneal fluid cytokines levels of women with endometriosis show indicate that an altered immune system may play an important role in the pathogenesis of endometriosis. The invasion of ectopic endometrium into peritoneal mesothelium, in association of different angiogenic factors, requires matrix metalloproteinases (MMPs) for tissue remodeling. Several MMPs are differentially expressed in human uterine endometrium with menstrual endometrium showing the highest level of expression. (Braundmeier et al., 2010)

MMP systems closely interact with PA system, because plasmin is an active enzyme, which degrades a variety of extracellular matrix proteins and activates MMPs and growth factors (Murphy et al., 2000). 
The catalytic domains of all MMPs share high amino acid similarity and their active sites are extensively conserved (Lauer-Fields et al., 2009). As a consequence, differenciate between different MMPs activities is extraordinarily difficult. However, some members of these proteases showed a role in the pathogenesis of endometriosis.

Matrix metalloproteinase 7 (MMP7): MMP7 is secreted mostly from the endometrial epithelium cells during the receptive phase localized to endometrial glandular and luminal epithelium (Yanaihara et al., 2004; Zhang et al., 2005)

Moreover, MMP-7 has been shown to be the dominant metalloproteinase during the initial development of endometriosis in a baboon model (Fazleabas et al., 2002). In addition, a recent study clearly demonstrated that MMP-7 mRNA was identified in host peritoneal tissues during the development of endometriosis in a nude mouse model (Hull et al., 2008)

MMP-7 protein expression in epithelial cells was significantly higher in red peritoneal lesions compared with that of deep infiltrating endometriosis, ovarian endometriosis and black peritoneal lesions, in all phases of the menstrual cycle. MMP-7 protein expression may be down-regulated during the evolution of peritoneal endometriotic implants, as active red lesions transition into inactive black lesions (Matsuzaki et al., 2010).

Matrix metalloproteinase 5 (MMP5): The strongest MMP5 staining was seen in luminal epithelial cells, whereas endometrial glands frequently showed partial expression.

Both the gene chip expression analyses as well as PCR indicated strongly elevated transcript levels in most peritoneal endometriosis lesions. Moreover enhanced MT5-MMP expression has been detected in the eutopic endometrium from patients suffering from endometriosis. (Gaetje et al., 2007)

Matrix metalloproteinase 3 (MMP3): IMMP-3 is hormonally regulated during the menstrual cycle, with the highest levels of expression occurring during menses local regulation that is absent in the in vitro cultures. (Hulboy et al., 1997;.)

MMP-3 has not been well studied in endometriosis, however, studies suggest that retrogradely shed menstrual fragments, the putative precursors of endometriotic lesions, express high levels of MMP- 3 (Koks et al., 2000).

Cox et al, demonstrated in a rat model that elevated MMP-3 expression by endometrial tissue leads to the establishment and progression of ectopic endometrial tissue growth. (KE. Cox, et al., 2001).

Significant expression differences were obtained for MMP3 in the ovarian endometriomas. The deregulation of the different genes, included MMP3 genes, may be responsible for the loss of cellular homeostasis in endometriotic lesions (Meola et al., 2010)

Matrix metalloproteinase 2 (MMP): Overexpression of stromal MMP-2 may play a role in the development of adenomyosis (Tokyol et al., 2009)

Matrix metalloproteinase 9 (MMP9): Eutopic endometrium of women with endometriosis compared with normal women showed an increased release of MMP-9, and a decreased release of its natural inhibitor, TIMP-1, at both the protein and the mRNA levels (Chen et al. 2004; Collette et al., 2004; Collette et al., 2006). 


\subsubsection{Genetic polymorphism of MMPs family}

Genetic polymorphisms located in the promoter region of the MMP genes could lead to increased gene expression and could be associated with predisposition to endometriosis (Ye, 2006). Nevertheless, the genetic susceptibility of endometriosis in relation to MMPs polymorphism is very complex, because for several polymorphisms, allele frequencies were found to be significantly different according to ethnic origin (MMP2.1, MMP2.2, MMP3 and MMP12).

Borghese et al., investigated the role of MMP1, MMP2, MMP3, MMP7, MMP12 and MMP13 polymorphisms as endometriosis risk factors in a case - control study of patients affected by superficial, deep infiltrating or endometrioma in the Caucasian population. The study found a potential role for MMP12 -82 A/G and MMP13 -77 A/G combined polymorphisms, which modulate transcriptional activity, in superficial endometriosis. As no association was found with deep infiltrating endometriosis, this combination of polymorphisms might protect from a more in-depth penetration of tissues (Borghese et al., 2008). On the other hand, they did not find any correlation between endometriosis and MMP1, MMP2, MMP3, MMP7 polymorphism (Borghese et al., 2008). Data regarding the lack of association between MMP1 e MMP-3 polymorphism and endometriosis susceptibility were confirmed in another study concerning the Italian population (Ferrari et al., 2006).

A case-control study in women of caucasian origin, evaluated the potential associations of MMP-2 and MMP-9 gene promoter region polymorphisms as well as MMP-2 promoter haplotypes with susceptibility to endometriosis. The results demonstrated that polymorphisms in MMP-2 (-735 C/T) and MMP-9 (-1562 C/T) were associated with elevated risk of endometriosis and that certain MMP-2 promoter haplotypes were more common in control group (Saare et al., 2010).

A genetic study regarding North Chinese women on three polymorphisms in the MMP-2 (MMP-2; -1306C-->T and -735C-->T) and TIMP-2 (TIMP-2; -418G-->C) genes found that the TIMP-2 -418C/C homozygote may be a protective factor against the development of endometriosis (Kang et al., 2008). A analogous study in the same population showed that MMP-7-181A/G polymorphism has a potential to be a susceptibility factor for endometriosis and adenomyosis while MMP-9-1562C/T polymorphism may not provide a useful marker to predict susceptibility to endometriosis and adenomyosis (Shan et al., 2006). On the other hand, an increase in the distribution of the MMP-9R279Q/P574R $(2678 \mathrm{G}>\mathrm{A} / 4859 \mathrm{C}>\mathrm{G})$ and $-1562 \mathrm{C}>\mathrm{T} / \mathrm{R} 668 \mathrm{Q} \quad(-1562 \mathrm{C}>\mathrm{T} / 5546 \mathrm{G}>\mathrm{A})$ haplotypes was significantly associated with endometriosis (Han et al., 2009).

\subsubsection{Relevance of MMPs serum/urinary levels as diagnostic markers}

The balance between MMPs and their inhibitors is preserved in the serum of women with endometriosis; however MMP-3 mRNA seems to be a promising peripheral blood marker that discriminates between patients with endometriosis and healthy subjects. Circulating mRNA for MMP-3 is significantly higher in patients with endometriosis than in control patients, regardless of the degree of severity. (De Sanctis et al., 2010).

Conversely, the clinical relevance of MMP-2 and MMP-9 as markers of endometriosis is controversial; some data report that serum concentrations of MMP-2, MMP-9, TIMP-1 and TIMP-2 cannot be considered to represent a valid measure of the severity of endometriosis 
(Salata et al., 2008; De Sanctis et al., 2010). On the other hand a prospective, blinded, longitudinal study show that MMP-2, MMP-9, and MMP-9/neutrophil gelatinase-associated lipocalin were significantly more likely to be detected in the urine of patients with endometriosis than in controls (Beker et al. 2010).

Bruner-Tran et al. described progesterone treatment inhibits expression of MMP-3 and -7 in human endometrium and prevents the establishment of ectopic lesions in a nude mouse model (Bruner-Tran et al., 2002).

A study concerning human endometrium intraperitoneally transplanted into nude mice, demonstrated a significant suppression of MMP-2 transcription by all progestins tested, and a significant down-regulation of MMP-3 by dydrogesterone (Mönckedieck et al., 2009).

In conclusion, angiogenesis is proposed as an important mechanism for the pathogenesis of endometriosis. Different evidences support the hypothesis that the endometrium of women with endometriosis has an increased capacity to proliferate, implant and grow in the peritoneal cavity. Further studies are needed to better understand critical steps of the pathogenesis of endometriosis; nevertheless excessive endometrial angiogenesis suggests novel new medical treatments.

\section{References}

Aeby TC, Huang T, Nakayama RT. The effect of peritoneal fluid from patients with endometriosis on human sperm function in vitro. Am J Obstet Gynecol 1996;174:1779-85

Akoum A, Jolicoeur C, Boucher A. Estradiol amplifies interleukin-1 induced monocyte chemotactic protein-1 by ectopic endometrial cells of womenwith endometriosis. J Clin Endocrinol Metab 2000; 85: 896-904.

Akoum A, Jolicoeur C, Kharfi A, Aube M. Decreased expression of the decoy interleukin-1 receptor type II in human endometriosis. Am J Pathol 2001;158:481-9.

Akoum A, Lemay A, Brunet C, Hebert J. Cytokine-induced secretion of monocyte chemotactic protein-1 by human endometriotic cells in culture. The Groupe d'Investigation en Gynecologie. Am J Obstet Gynecol 1995;172:594-600.

Akoum A, Lemay A, Maheux R. Estradiol and interleukin-1beta exert a synergistic stimulatory effect on the expression of the chemokine regulated upon activation, normal $\mathrm{T}$ cell expressed, and secreted in endometriotic cells. J Clin Endocrinol Metab 2002;87:5785-92.

Akoum A, Lemay A, Paradis L, Rheault N, Maheux R. Secretion of interleukine-6 by human endometriotic cells and regulation by proinflammatory cytokines and sex steroids. Hum Reprod 1996; 11: 2269-2275.

Akoum A, Mahera Al-Akoum, Andre Lemay, Rodolphe Maheux,Mathieu Leboeuf. Imbalance in the peritoneal levels of interleukin 1 and its decoy inhibitory receptor type II in endometriosis nwomen with infertility and pelvic pain. Fertility and Sterility 2008; 89, 6.

American Society for Reproductive Medicine. Revised American Society for Reproductive Medicine classification of endometriosis. Fertil Steril 1997; 67: 817-821. 
Arci A, Seli E, Zeyneloglu HB, Senturk LM, Oral E, Olive DL. Interleukin-8 induces proliferation of endometrial stromal cells: a potential autocrine growth factor. J Clin Endocrinol Metab 1998; 83: 1201-1205.

Arici A, Tazuke SI, Attar E, Kliman HJ, Olive DL. Interleukin-8 concentration in peritoneal fluid of patients with endometriosis and modulation of interleukin-8 expression in human mesothelial cells. Mol Hum Reprod 1996;2:40-45. 28.

Arumugam K. Endometriosis and infertility: raised iron concentration in the peritoneal fluid and its effect on the acrosome reaction. Hum Reprod 1994;9:1153-7.

Becker CM, Louis G, Exarhopoulos A, Mechsner S, Ebert AD, Zurakowski D, Moses MA. Matrix metalloproteinases are elevated in the urine of patients with endometriosis. Fertil Steril. 2010 Nov;94(6):2343-6. Epub 2010 Apr 7.

Bedaiwy MA, Falcone T, Sharma RK et al. Prediction of endometriosis with serum and peritoneal markers: a prospective controlled trial. Hum Reprod 2002; 17: 426- 431

Betjes MGH, Tuk CW, Struik DG, Kredict RT, Arisz L, Hart M, et al. Interleukin-8 production by human peritoneal mesothelial cells in response to tumor necrosis factor-a, interleukin-1, and medium conditioned by macrophages co-cultured with Staphylococcus epidermidis. J Infect Dis 1993;168:1202-10.

Borghese B, Chiche JD, Vernerey D, Chenot C, Mir O, Bijaoui G, Bonaiti-Pellié C, Chapron C. Genetic polymorphisms of matrix metalloproteinase 12 and 13 genes are implicated in endometriosis progression. Hum Reprod. 2008 May;23(5):1207-13. Epub 2008 Feb 28.

Bossu P, Visconti U, Ruggiero P, Macchia G, Muda M, Bertini R, et al. Transfected type II interleukin- 1 receptor impairs responsiveness of human keratinocytes to interleukin- 1. Am J Pathol 1995;147:1852-61.

Boyle, J. J. . Macrophage activation in atherosclerosis: pathogenesis and pharmacology of plaque rupture. Curr Vasc Pharmacol, 3(1), 63-68. (2005)

Braun D.P., Jianchi Ding, W. Paul Dmowski. Peritoneal fluid-mediated enhancement of eutopic and ectopic endometrial cell proliferation is dependent on tumor necrosis factor- $\square$ in women with endometriosis . Fertil Steril, 78,4,OCTOBER 2002

Braundmeier AG, Fazleabas AT, Nowak RA. Extracellular matrix metalloproteinase inducer expression in the baboon endometrium: menstrual cycle and endometriosis. Reproduction 2010 Dec;140(6):911-20. Epub 2010 Sep 14.

Bruner KL, Rodgers WH, Gold LI, Korc M, Hargrove JT, Matrisian LM, Osteen KG. Transforming growth factor-b mediates the progesterone suppression of an epithelial metalloproteinase by adjacent stroma in the human endometrium. Proc Natl Acad Sci USA 1995;92:7362-7366

Bruner-Tran KL, Eisenberg E, Yeaman GR, Anderson TA, McBean J, Osteen KG Steroid and cytokine regulation of matrix metalloproteinase expression in endometriosis and the establishment of experimental endometriosis in nude mice. J Clin Endocrinol Metab 2002;87:4782-4791.

Bruse C, Gan Y, Carlberg M, Carlström K, Bergqvist A. Basal release of urokinase plasminogen activator, plasminogen activator inhibitor-1, and soluble plasminogen activator receptor from separated and cultured endometriotic and endometrial stromal and epithelial cells. Fertil Steril. 2005 Apr;83 Suppl 1:1155-60

Chegini N, Zhao Y, Williams RS, Flanders KC. Human uterine tissue throughout the menstrual cycle expresses transforming growth factor-b1 (TGFb1), TGFb2, TGFb3, 
and TGFb type II receptor messenger ribonucleic acid and protein and contains [125I]TGFb1-binding sites. Endocrinology 1994;135:439-449.

Chen QH, Qu JY, Xu YY, Qiu NX, Zhuang YZ, Zhong S, Fang QQ [Expressions of matrix metalloproteinase-9 and tissue inhibitor of metalloproteinase-1 in ectopic and eutopic endometrium]. Zhonghua Fu Chan Ke Za Zhi 2004;39:809-812.

Collette T, Bellehumeur C, Kats R, Maheux R, Mailloux J, Villeneuve M, Akoum A. Evidence for an increased release of proteolytic activity by the eutopic endometrial tissue in women with endometriosis and for involvement of matrix metalloproteinase-9. Hum Reprod 2004;19:1257-1264.

Collette T, Maheux R, Mailloux J, Akoum A Increased expression of matrix metalloproteinase-9 in the eutopic endometrial tissue of women with endometriosis. Hum Reprod. 2006 Dec;21(12):3059-67. Epub 2006 Jul 31.

Colotta F, Re F, Muzio M, Bertini R, Polentarutti N, Sironi M, et al. Interleukin-1 type II receptor: a decoy target for IL-1 that is regulated by IL-4. Science 1993;261:472-5.

Cosín R, Gilabert-Estellés J, Ramón LA, Gómez-Lechón MJ, Gilabert J, Chirivella M, BrazaBoïls A, España F, Estellés A.Influence of peritoneal fluid on the expression of angiogenic and proteolytic factors in cultures of endometrial cells from women with endometriosis. Hum Reprod. 2010 Feb;25(2):398-405. Epub 2009 Nov 26.

Cox KE, Piva M and Sharpe-Timms KL (2001) Differential regulation of matrix metalloproteinase-3 gene expression in endometriotic lesions compared with endometrium. Biol Reprod 65,1297 - 1303.

Cui X, Rouhani FN, Hawari F, Levine SJ. Shedding of the type II IL-1 decoy receptor requires a multifunctional aminopeptidase, aminopeptidase regulator of TNF receptor type 1 shedding. J Immunol 2003;171: 6814-9.

Curtis P, Jackson AE. Adverse effects on sperm movement characteristics in women with minimal and mild endometriosis. Br J Obstet Gynecol 1993;100:165-9.

D'Antonio M, Martelli F, Peano S, Papoian R, Borrelli F. Ability of recombinant human TNF binding protein-1 (r-hTBP-1) to inhibit the development of experimentally-induced endometriosis in rats. J Reprod Immunol 2000;48:81-98.

Daniel T. Rein M.D. Torsten Schmidt M.D., et al (2010) Treatment of endometriosis with a VEGF-targeted conditionally replicative adenovirus. Fertil Steril Vol93 (8): 26872694

De Sanctis P, Elmakky A, Farina A, Caramelli E, Seracchioli R, Mabrouk M, Mignemi G, Venturoli S, Villa G, Guerrini M, Manuzzi L, Montanari G, Valvassori L, Zucchini C. Matrix metalloproteinase-3 mRNA: a promising peripheral blood marker for diagnosis of endometriosis. Gynecol Obstet Invest. 2011;71(2):118-23. Epub 2010 Dec 9.

Derynck R, Akhurst RJ, Balmain A. TGF-b signaling in tumor suppression and cancer progression. Nat Genet 2001;29:117-129.

Di Carlo C, Bonifacio M, Tommaselli G et al (2009). Metalloproteinases, vascular endothelial growth factor and angiopoietin 1 and 2 in eutopic and ectopic endometrium. Fertil Steril 91:2316-2323.

Dinarello CA. Therapeutic strategies to reduce IL-1 activity in treating local and systemic inflammation. Curr Opin Pharmacol 2004;4:378-85. 
Ding J, Shen M, Gogacz M, Braun DP, Rana N, Dmowski WP. Endometrial apoptosis is inhibited in vitro by TNF-alfain women with endometriosis and is stimulated by TNF-alfa in healthy women. J Soc Gynecol Invest 2000; 47:218A.

Drudy L, Lewis SEM, Kinsella CB, Harrison RF, Thompson W. The influence of peritoneal fluid from patients with minimal stage or treated endometriosis on sperm motility parameters using computerassisted semen analysis. Hum Reprod 1994;9:2418 -23

Essam-Eldin R. Othman M.D , Salama Salama Ph.D., Nahed Ismail Ph.D., M.D. and Ayman Al-Hendy Ph.D., M.D. (2007)Toward gene therapy of endometriosis: adenovirusmediated delivery of dominant negative estrogen receptor genes inhibits cell proliferation, reduces cytokine production, and induces apoptosis of endometriotic cells. Fertility and Sterility Volume 88, Issue 2, , Pages 462-471

Fakih H, Baggett B, Holtz G, Tsang K-Y, Lee JC, Williamson HO. Interleukin-1: possible role in the infertility associated endometriosis. Fertil Steril 1987;47:213-7.

Fasciani A., D’Ambrogio G., Monti M., Bocci G, Genazzani A.R., Artini P.G. (2000) High concentration of the vascular endothelial growth factor and interleukin- 8 in ovarian endometrioma. Mol.Hum. Reprod. Vol 6., $\mathrm{n}^{\circ} 1: 50-54$

Fazleabas AT, Brudney A, Gurates B, Chai D, Bulun S. A modified baboon model for endometriosis. Ann N Y Acad Sci 2002;955:308 - 317.).

Fengying, H, Qiuhong L, Huaping w et al (2010). Effect of Gnrh II on secretion of VEGF by eutopic and ectopic endometrial stromal cells of endometriosis patients. J Cent South Univ (Med Sci) 35(5)

Fernández-Shaw S, Marshall JM, Hicks B, Barlow DH, Starkey PM. Plasminogen activators in ectopic and uterine endometrium. Fertil Steril. 1995 Jan;63(1):45-51.

Ferrari MM, Biondi ML, Rossi G, Grijuela B, Gaita S, Perugino G, Viganò P. Analysis of two polymorphisms in the promoter region of matrix metalloproteinase 1 and 3 genes in women with endometriosis. Acta Obstet Gynecol Scand. 2006;85(2):212-7.

Fraser HM and Lunn SF (2000) Angiogenesis and its control in the female reproductive system. Br Med Bull 56:787-797.

Gaetje R, Holtrich U, Engels K, Kourtis K, Cikrit E, Kissler S, Rody A, Karn T, Kaufmann M. Expression of membrane-type 5 matrix metalloproteinase in human endometrium and endometriosis. Gynecol Endocrinol. 2007 Oct;23(10):567-73.

Gaide Chevronnay HP, Cornet PB, Delvaux D, Lemoine P, Courtoy PJ, Henriet P, Marbaix E. Opposite regulation of transforming growth factor-b2 and -b3 expression in the human endometrium. Endocrinology 2008; 149:1015-1025

Garcia-Velasco JA, Arici A, Zreik T, Naftolin F, Mor G. Macrophagederived growth factors modulate Fas ligand expression in cultured endometrial stromal cells: a role in endometriosis. Mol Hum Reprod 1997;5:642-650.

Garcia-Velasco JA, Arici A. Interleukin-8 stimulates the adhesion of endometrial stromal cells to fibronectin. Fertil Steril 1999; 72: 336-340.

Gentilini D, Somigliana E, Vigano P, et al (2008). The vascular endothelial growth factor $+405 \mathrm{G}>$ C polymorphism in endometriosis. Hum Reprod. 23:211-215.

Gilabert-Estelles J, Ramon LA, Espana F et al. (2007) Expression of angiogenic factors in endometriosis: relationship to fibrinolytic and metalloproteinase systems. Hum Reprod, 22:2120-2127.

Giudice LC, Kao LC. Endometriosis (review). Lancet 2004; 364:1789 - 1799.; Hull ML, Escareno CR, Godsland JM, Doig JR, Johnson CM, Phillips SC, Smith SK, Tavare S, 
Print CG, Charnock-Jones DS. Endometrial-peritoneal interactions during endometriotic lesion establishment. Am J Pathol 2008;173:700 - 715).

Gilman A, Goodman LS, Hardman JG, Limbird LE Goodman \& Gilman's the pharmacological basis of therapeutics. New York: McGraw-Hill. ISBN 0-07-1354697. (2001).

Gold LI, Saxena B, Mittal KR, Marmor M, Goswami S, Nactigal L, Korc M, Demopoulos RI. Increased expression of transforming growth factorb isoforms and basic fibroblast growth factor in complex hyperplasia and adenocarcinoma of the endometrium: evidence for paracrine and autocrine action. Cancer Res 1994;54:2347-2358.

Gordon, J., Shifren, J., Foulk, R. et al. (1995) Angiogenesis in the human female reproductive tract. Obstet. Gynecol. Surv., 50, 688-697.

Goteri G, Lucarini G, Filosa A et al (2004) Immunoistochimical analysis of vascular endothelial growth factor cellular expression in ovarian endometrioma. Fertil Steril 81: 1528-1533

Goteri G, Lucarini G, Zizzi A, et al (2010) Proangiogenetic molecole, hypoxia-inducible factor 1- $\alpha$ and nitric oxide synthase isoforms in ovarian endometirotic cyst. Virchows Arch 456: 703-710.

Grancha S, Estelles A, Gilabert J, Chirivella M, Espana F, Aznar J and Loskutoff DJ (1996) Decreased expression of PAI-2 mRNA and protein in pregnancies complicated with intrauterine fetal growth retardation. Thromb Haemostas 76,761 - 767.

Groothuis PG, Nap AW, Winterhager E, Grümmer R. Vascular development in endometriosis Angiogenesis. 2005;8(2):147-56. Epub 2005 Oct 7. Review.

Guan YM, Carlberg M, Bruse C, Carlström K, Bergqvist A. Effects of hormones on uPA, PAI-1 and suPAR from cultured endometrial and ovarian endometriotic stromal cells. Acta Obstet Gynecol Scand. 2002 May;81(5):389-97.);

Halme J, Becker S, Wing R. Accentuated cyclic activation of peritoneal macrophages in patients with endometriosis. Am J Obstet Gynecol 1984;148:85-90

Halme J. Release of tumor necrosis factor-a by human peritoneal macrophages in vivo and vitro. Am J Obstet Gynecol 1989;161:1718- 25.

Han YJ, Kim HN, Yoon JK, Yi SY, Moon HS, Ahn JJ, Kim HL, Chung HW.

Haplotype analysis of the matrix metalloproteinase- 9 gene associated with advanced-stage endometriosis. Fertil Steril. 2009 Jun;91(6):2324-30. Epub 2008 Jun 12.

Harada T, Enatsu A, Yoshida S et al. Increased interleukin-6 levels in peritoneal fluid of infertile patients with active endometriosis. Am J Obstet Gynecol 1997; 176: 593 597.

Harada T, Iwabe T, Terakawa N. Role of cytokines in endometriosis. Fertil Steril 2001;76:110.

Harada T, Terakawa N. Cytokines in peritoneal fluid from women with active endometriosis. In: Minaguchi H, Sugimoto O (eds). Endometriosis today. New York: Parthenon, 1997:144-8.

Harada T, Yoshioka H, Yoshida S, Iwabe T, Onohara Y, Tanikawa M, et al. Increased interleukin-6 levels in peritoneal fluid of infertile patients with active endometriosis. Am J Obstet Gynecol 1997;176: 593-7.

Harbeck N, Kruger A, Sinz S, Kates RE, Thomssen C, Schmitt M and Janicke F (2001) Clinical relevance of the plasminogen activator inhibitor type 1-a multifaceted proteolytic factor. Onkologie 24,238 - 244. 
Heeb MJ, Espana F, Geiger M, Collen D, Stump DC and Griffin JH (1987) Immunological identity of heparine dependent plasma and urinary protein $\mathrm{C}$ inhibitor and plasminogen activator inhibitor-3. J Biol Chem 262, 15813 - 15816.

Hyder SM, Stancel GM. Regulation of angiogenic growth factors in the female reproductive tract by estrogens and progestins. Mol Endocrinol. 1999 Jun;13(6):806-11. Review.

Ho HN, Wu MY, Chao KH, Chen CD, Chen SU, Yang YS. Peritoneal interleukin-10 increases with decrease in activated CD4p T lymphocytes in women with endometriosis. Hum Reprod 1997;12:2528-2533.]

Hodgen GD. Peritoneal fluid from patients with endometriosis decreases sperm binding to the zona pellucida in the hemizona assay: a preliminary report. Fertil Steril 1992;57:783- 6.

Hulboy DL, Rudolph LA, Matrisian LM. Matrix metalloproteinases as mediators of reproductive function. Mol Hum Reprod 1997; 3:27- 45.

Hull ML, Escareno CR, Godsland JM, Doig JR, Johnson CM, Phillips SC, Smith SK, Tavare S, Print CG, Charnock-Jones DS. Endometrial-peritoneal interactions during endometriotic lesion establishment. Am J Pathol 2008;173:700 - 715.

Hyder SM, Stancel GM (1999) Regulation of angiogenic growth factors in the female $r$ eproductive tract by estrogens and progestins. Mol Endocrinol 13:806-811.

Imesch P, Samartzis E, Schneider M et al ( 2011).Inhibition of transcription, expression, and secretion of the vascular epithelial growth factor in human epithelial endoemtriotic cells by romidepsin. Fertil Steril. 95(5):1580-1583.

Iwabe T, Harada T, Terakawa N. Role of cytokines in endometriosis-associated infertility. Gynecol Obstet Invest 2002;53(Suppl 1):19-25.

Iwabe T, Harada T, Tsudo T, Nagano Y, Tanikawa M, Terakawa N. Tumor necrosis factor-a promotes proliferation of the endometrio tic stromal cells by inducing interleukin- 8 gene and protein expression. J Clin Endocrinol Metab 2000;85:824 -9

Iwabe T, Harada T, Tsudo T, Tanikawa M, Onohara Y, Terakawa N. Pathogenetic significance of increased levels of interleukin-8 in peritoneal fluid of patients with endometriosis. Fertil Steril 1998;69:924- 30.

Jacobs AL, Sehgal PB, Julian J, Carson DD. Secretion and hormonal regulation of interleukine- 6 production by mouse uterine stromal and polarized epithelial cells cultured in vitro. Endocrinology 1992; 131: 1037-1045.

Johnson MC, Torres M, Alves A, Bacallao K, Fuentes A, Vega M, Boric MA. Augmented cell survival in eutopic endometrium from women with endometriosis: expression of cmyc, TGF-beta1 and bax genes. Reprod Biol Endocrinol 2005;3:45.

Jolicoeur C, Boutouil M, Drouin R, Paradis I, Lemay A, Akoum A. Increase expression of monocyte protein- 1 in the endometrium of women with endometriosis. Am J Pathol 1998; 152: 125-133.

Jones RL, Stoikos C, Findlay JK, Salamonsen LA. TGF-ß superfamily expression and actions in the endometrium and placenta. Reproduction 2006;132:217-232.

Kaliński P, Hilkens CM, Snijders A, Snijdewint FG, Kapsenberg ML (1997). "IL-12-deficient dendritic cells, generated in the presence of prostaglandin E2, promote type 2 cytokine production in maturing human naive T helper cells". J. Immunol. 159 (1): 28-35.

Kalu E, Nazira Sumar, Theodoros Giannopoulos, Pinika Patel, Carolyn Croucher, Elizabeth Sherriff,Amolak Bansal. Cytokine profiles in serum and peritoneal fluid from 
infertile women with and without endometriosis. J. Obstet. Gynaecol. Res. Vol. 33, No. 4: 490-495, August 2007

Kang S, Zhao XW, Wang N, Chen SC, Zhou RM, Li Y. Association of polymorphisms of the MMP-2 and TIMP-2 genes with the risk of endometriosis in North Chinese women. Fertil Steril. 2008 Nov;90(5):2023-9. Epub 2008 Jan 4.

Keenan JA, Chen TT, Chadwell NL, Torry DS, Caudle MR. IL-1 beta, TNF-alpha, and IL-2 in peritoneal fluid and macrophage-conditioned media of women with endometriosis. Am J Reprod Immunol 1995;34: 381-5

Kharfi A, Akoum A. Soluble interleukin-1 receptor type II blocks monocyte chemotactic protein-1 secretion by U937 cells in response to peripheral blood serum of women with endometriosis. Fertil Steril 2002;78: 836-42.).

Kharfi A, Boucher A, Akoum A. Abnormal interleukin-1 receptor type II gene expression in the endometrium of women with endometriosis. Biol Reprod 2002;66:401-6.

Kimatrai M, Oliver C, Abadia-Molina AC, Garcia-Pacheco JM, Olivares EG. Contractile activity of human decidual stromal cells. J Clin Endocrinol Metab 2003;88:844-849

Kimura H, Weisz A, Ogura T, Hitomi H, Kuraschima Y, Hashimoto K et al. (2001) Identification of hypoxia-inducible factor-1 ancillaty sequence and its function in vascular endothelial growth factor gene induction by hypoxia and nitric oxide. $J$. Biol. Chem 276:2292-2298.

Kobayashi M, Fitz L, Ryan M, Hewick RM, Clark SC, Chan S, et al. Identification and purification of natural killer cell stimulatory factor (NKSF), a cytokine with multiple biologic effects on human lymphocytes. J Exp Med 1989;170:827- 45.

Koks CA, Groothuis PG, Slaats P, Dunselman GA, de Goeij AFPM, Evers JLH. Matrix metalloproteinases and their tissue inhibitors in antegradely shed menstruum and peritoneal fluid. Fertil Steril 2000; 73:604 -612.

Komiyama S, Aoki D, Komiyama M, Nozawa S. Local activation of TGF-beta1 at endometriosis sites. J Reprod Med 2007;52:306-312.

Koninckx et al., 1998, 1999; Harada et al., 2001; Braun et al., 2002; Bedaiwy and Falcone, 2003; Kalu et al., 2007

Kothapalli R, Buyuksal I, Wu SQ, Chegini N, Tabibzadeh S. Detection of ebaf, a novel human gene of the transforming growth factor beta superfamily association of gene expression with endometrial bleeding.J Clin Invest 1997;99:2342-2350.

Kruithof EKO, Baker MS and Bunn CL (1995) Biological and clinical aspects of plasminogen activator inhibitor type 2. Blood 86,4007 - 4024.Gynecol Reprod Biol 95,167 - 174.

Lauer-Fields, J. L., Chalmers, M. J., Busby, S. A., Minond, D., Griffin, P. R., and Fields, G. B. (2009) Identification of specific hemopexin-like domain residues that facilitate matrix metalloproteinase collagenolytic activity. J Biol Chem 284, 24017-24024

Lebovic DI, Bentzien F, Chao VA, Garrett EN, Meng YG, Taylor RN. Induction of an angiogenic phenotype in endometriotic stromal cell cultures by interleukin-1beta. Mol Hum Reprod 2000;6:269-75.

Lee K, Lee Y, Chan R, et al (2010). Up-regulation of endocrine gland-derived vascular endothelial growth factor but not vascular endothelial growth factor but not vascular endothelial growth factor in human ectopic endometriotic tissue. Fertil Steril 4:1053-1060.

Lembessis P, Milingos S, Michalas S, Milingos D, Creatsas G, Sourla A, Koutsilieris M.Urokinase-type plasminogen activator and insulin-like growth factor-binding 
protein 3 mRNA expression in endometriotic lesions and eutopic endometrium: implications for the pathophysiology of endometriosis. Ann N Y Acad Sci. 2003 Nov;997:223-8.

Luo X, Xu J, Chegini N. The expression of Smads in human endometrium and regulation and induction in endometrial epithelial and stromal cells by transforming growth factor-b. J Clin Endocrinol Metab 2003; 88:4967-4976.

Machado DE, Berardo PT, Palmero CY, Nasciutti LE (2010). Higher express of vascular endothelial growth factor (VEGF) and its receptor VEGFR-2 (Flk-1) and metalloproteinase-9 (MMP-9) in a rat model of peritoneal endometirosis is similar to cancer. Journal of Experiment EClinical Cancer Resarch, 29:4

Marbaix E, Kokorine I, Donnez J, Eeckhout Y and Courtoy PJ (1996) Regulation and restricted expression of interstitial collagenase suggest a pivotal

Matrisian LM (1990) Metalloproteinases and their inhibitors in matrix remodelling. Trends Genet 12,121 - 125.

Matrisian LM (1992) The matrix-degrading metalloproteinases. BioEssays 14,455 - 463.

Matsuzaki S, Maleysson E, Darcha C. Analysis of matrix metalloproteinase-7 expression in eutopic and ectopic endometrium samples from patients with different forms of endometriosis. Hum Reprod. 2010 Mar;25(3):742-50. Epub 2009 Dec 10.

McLaren, J., Prentice, A., Charnock-Jones, D.S. et al. (1996a) Vascular endothelial growth factor is produced by peritoneal fluid macrophages in endometriosis and is regulated by ovarian steroids. J. Clin. Invest., 98, 482-489.

McLaren J (2000) Vascular endothelial growth factor and endometriotic angiogenesis. Hum Reprod Update. Jan-Feb;6(1):45-55. Review.

Meola J, Rosa e Silva JC, Dentillo DB, da Silva WA Jr, Veiga-Castelli LC, Bernardes LA, Ferriani RA, de Paz CC, Giuliatti S, Martelli L. Differentially expressed genes in eutopic and ectopic endometrium of women with endometriosis. Fertil Steril. 2010 Apr;93(6):1750-73. Epub 2009 Feb 6.

Meresman GF, Bilotas M, Buquet RA, Baranao RI, Sueldo C, Tesone M. Gonadotropinreleasing hormone agonist induces apoptosis and reduces cell proliferation in eutopic endometrial cultures from women with endometriosis. Fertil Steril 2003;80(Suppl. 2):702-707.

Minici F, Tiberi F, Tropea A, Orlando M , Gangale M.F.,Romani F , Campo S , A Bompiani , A Lanzone, Apa R .Endometriosis and human infertility: a new investigation into the role of eutopic endometrium Hum Repr ;23,3;530-537, 2008

Mönckedieck V, Sannecke C, Husen B, Kumbartski M, Kimmig R, Tötsch M, Winterhager E, Grümmer R. Progestins inhibit expression of MMPs and of angiogenic factors in human ectopic endometrial lesions in a mouse model. Mol Hum Reprod. 2009 Oct;15(10):633-43. Epub 2009 Aug 11

Mori H, Sawairi M, Nakagawa M, Itoh N,Wada K, Tamaya T. Peritoneal fluid interleukin-1 beta and tumor necrosis factor in patients with benign gynecologic disease. Am J Reprod Immunol 1991;26:62-7.

Murphy G, Kna " uper V, Atkinson A, Gavrilovic J and Edwards D (2000) Cellular mechanisms for focal proteolysis and the regulation of the microenvironment. Fibrinolysis Proteolysis 14,165 - 174. 
Muscato JJ, Haney AF, Weinberg JB. Sperm phagocytosis by human peritoneal macrophages: a possible cause of infertility in endometriosis. Am J Obstet Gynecol 1982;144:503-10.

Nasu K, Nishida M, Matsumoto H, Bing S, Inoue C, Kawano Y, Miyakawa I. Regulation of proliferation, motility and contractivity of cultured human endometrial stromal cells by transforming growth factor-beta isoforms. Fertil Steril 2005;84(Suppl. 2):1114-1123.

Neufeld G, Cohen T, Gengrinovitch S, and Poltorak Z (1999) Vascular endothelial growth factor (VEGF) and its receptors. FASEB J 13:9-22.

Nisolle, M., Casanas-Roux, F., Anaf, V. et al. (1993) Morphometric study of the stromal vascularization in peritoneal endometriosis. Fertil. Steril., 59, 681-684.

Oosterlynck D, Meuleman M, Waer M, Koninckx P. Transforming growth factor-betaactivity is increased in peritoneal fluid from women with endometriosis. Obstet Gynecol 1994;83:287-92.

Orlando S, Sironi M, Bianchi G, Drummond AH, Boraschi D, Yabes D, et al. Role of metalloproteases in the release of the IL-1 type II decoy receptor. J Biol Chem 1997;272:31764-9.

Ortega N, Hutchings H, and Plouet J (1999) Signal relays in the VEGF system. Front Biosci 4:D141-D152.

Overton C, Fernandez-Shaw S, Hicks B, Barlow D, Starkey P. Peritoneal fluid cytokines and the relationship with endometriosis and pain. Hum Reprod 1996;11:380-386.

P.G Artini, M.Ruggiero, P. Monteleone, A. Carpi, F. Cristello, V. Cela, A.R. Genazzani (2008) Vascular endothelial growth factor and its soluble receptor in benign and malignant ovarian tumors. Biomedicine \& Pharmacotherapy 62:373e377

Pizzo A, Salmeri F, Ardita F, Sofo V, Tripepi M, Marsico S. Behaviour of cytokine levels in serum and peritoneal fluid of women with endometriosis. Gynecol Obstet Invest 2002; 54: 82-87.

Punnonen J, Teisala K, Ranta H, Benneff B, Punnonen R. Increased level of interleukin-6 and interleukin-10 in peritoneal fluid of patients with endometriosis. Am J Obstet Gynecol 1996; 174: 1522-1526

Rana N, Gebel H, Braun DP, Rotman C, House R, Dmowski WP. Basal and stimulated secretion of cytokines by peritoneal macrophages in women with endometriosis. Fertil Steril 1996;65:925-30). role in the initiation of menstruation. Hum Reprod 11,134-143.

Ryan IP, Tseng JF, Schriock ED, Khoram O, Landers DV, Taylor RN. Interleukin-8 concentrations are elevated in the peritoneal fluid of women with endometriosis. Fertil Steril 1995; 63: 929-932.

Saare M, Lamp M, Kaart T, Karro H, Kadastik U, Metspalu A, Peters M, Salumets A. Polymorphisms in MMP-2 and MMP-9 promoter regions are associated with endometriosis. Fertil Steril. 2010 Sep;94(4):1560-3. Epub 2010 Jan 25.

Sakamoto Y, Harada T, Horie S, Iba Y, Taniguchi F, Yoshida S, Iwabe T, Terakawa N. Tumor necrosis factor-ainduced interleukin-8 (IL-8) expression in endometriotic stromal cells, probably through nuclear factor- $\mathrm{kB}$ activation: gonadotropin-releasing hormone agonist treatment reduced IL-8 expression. J Clin Endocrinol Metab 2003;88:730-735. 
Salamonsen LA and Woolley DE (1996) Matrix metalloproteinases in normal menstruation. Hum Reprod 11,124 - 133.

Salata IM, Stojanovic N, Cajdler-Łuba A, Lewandowski KC, Lewiński A. Gelatinase A (MM2), gelatinase B (MMP-9) and their inhibitors (TIMP 1, TIMP-2) in serum of women with endometriosis: Significant correlation between MMP-2, MMP-9 and their inhibitors without difference in levels of matrix metalloproteinases and tissue inhibitors of metalloproteinases in relation to the severity of endometriosis. Gynecol Endocrinol. 2008 Jun;24(6):326-30.

Sampson J (1927). Metastatic or Embolic Endometriosis, due to the Menstrual Dissemination of Endometrial Tissue into the Venous Circulation. Am J Pathology 3(2): 93-110.43.

Scott RB, Te Linde RW, Wharton LR Jr. Further studies on experimental endometriosis. Am J Obstet Gynecol 1953;60:1082-103.

Shan K, Lian-Fu Z, Hui D, Wei G, Na W, Xia J, Yan L. Polymorphisms in the promoter regions of the matrix metalloproteinases-7, -9 and the risk of endometriosis and adenomyosis in China. Mol Hum Reprod. 2006 Jan;12(1):35-9. Epub 2006 Feb 2.

Shull MM, Ormsby I, Kier AB, Pawlowski S, Diebold RJ, Yin M, Allen R, Sidman C, Proetzel $\mathrm{G}$, Calvin D et al. Targeted disruption of the mouse transforming growth factor-b1 gene results in multifocal inflammatory disease. Nature 1992;359:693-699.

Sillem M, Prifti S, Monga B, Buvari P, Shamia U, Runnebaum B. Soluble urokinase-type plasminogen activator receptor is over-expressed in uterine endometrium from women with endometriosis. Mol Hum Reprod. 1997 Dec;3(12):1101-5.

Simpson JL,Bischoff FZ, Kamat A, et al. (2003). Genetics of endometriosis. Obstet Gynecol Clin North Am.30:21-40.

Smith RE, Hogaboam CM, Strieter RM, Lukas NW, Kunkel SL. Cell-to-cell and cell-to-matrix interactions mediate chemokine expression: an important component of the inflammatory lesion. J Leukoc Biol 1997;62:612-9.

Somigliana S, Vigano P, Rossi G, Carinelli S, Vignali M, Panina- Bordignon P. Endometrial ability to implant in ectopic sites can be prevented by interleukin-12 in a murine model of endometriosis Hum Reprod 1999;14:2944 -50.

Spuijbroek MDE, Dunselman GAJ, Menheere PPCA, Evers JLH. Early endometriosis invades the extracellular matrix. Fertil Steril 1992;58:929 -33

Subramaniam S, Stansberg C, Cunningham C. The interleukin 1 receptor family. Dev Comp Immunol 2004;28:415-28.

Sueldo CE, Kelly E, Montoro L, Subias E, Baccaro M, Swanson JA, et al. Effect of interleukin1 on gamete interaction and mouse embryo development. J Reprod Med 1990;35:868-72.

Suginami H, Yano K. An ovum capture inhibitor (OCI) in endometriosis peritoneal fluid: an OCI-related membrane responsible for fimbrial failure of ovum capture. Fertil Steril 1988;50:648 -53.

Symons JA, Young PR, Duff GW. Soluble type II interleukin 1 (IL-1) receptor binds and blocks processing of IL-1 beta precursor and loses affinity for IL-1 receptor antagonist. Proc Natl Acad Sci USA 1995;92: 1714-8.

Syrop CH, Halme J. Peritoneal fluid environment and infertility. Fertil Steril 1987;48:1-9)

Tabibzadeh S, Mason JM, Shea W, Cai Y, Murray MJ, Lessey B Dysregulated expression of ebaf, a novel molecular defect in the endometria of patients with infertility. J Clin Endocrinol Metab 2000; 85:2526-2536. 
Tabibzadeh S, Santhanam V, Sehgel PB, May LT. Cytokine-induced production of IFN-b2 by freshly explanted human endometrial stromal cells. Modulation by estradiol-17b. J Immunol 1989;142:3134 -9.

Tabibzadeh S. Homeostasis of extracellular matrix by TGF-beta and lefty. Front Biosci 2002;7:d1231-d1246.

Taketani Y, Kuo TM, Mizuno M. Comparison of cytokine levels and embryo toxicity in peritoneal fluid in infertile women with untreated or treated endometriosis. Am J Obstet Gynecol 1992;167:265-70.

Tamburro S, Canis M, Albuisson E, Dechelotte P, Darcha C, Mage G.Expression of transforming growth factorb1 in nerve fibers is related to dysmenorrhea and laparoscopic appearance of endometriotic implants. Fertil Steril 2003;80:1131-1136.

Tamura M, Fukaya T, Enomoto A, Murakami T, Uehara S, Yajima A Transforming growth factor-beta isoforms and receptors in endometriotic cysts of the human ovary. Am J Reprod Immunol 1999;42:160-167

Tokyol C, Aktepe F, Dilek FH, Sahin O, Arioz DT. Expression of cyclooxygenase-2 and matrix metalloproteinase- 2 in adenomyosis and endometrial polyps and its correlation with angiogenesis. Int J Gynecol Pathol. 2009 Mar;28(2):148-56.

Tsudo T, Harada T, Iwabe T, Tanikawa M, Nagano Y, Ito M, Taniguchi F, Terakawa N. Altered gene expression and secretion of interleukin-6 in stromal cells derived from endometriotic tissues. Fertil Steril 2000;73:205-211

Ulloa L, Tabibzadeh S. Lefty inhibits receptor-regulated Smad phosphorylation induced by the transforming growth factor-beta receptor. J Biol Chem 2001;276:21397-21404.

Vinatier D, Dufour P, Oosterlynck D. Immunological aspects of endometriosis. Hum Reprod Update 1996;2:371- 84.

Wiegerick MAHM, Van Dop PA, Brosens IA. The staging of peritoneal endometriosis by the type active lesion in addition to the revised American Fertility Society classification. Fertil Steril 1993;60:461- 4

Wysocka M, Kubin M, Vieira LQ, Ozmen L, Garotta G, Scott P, et al. Interleukin-12 is required for IFN- production and lethality in lipopolysaccharide- induced shock in mice. Eur J Immunol 1995;25:672- 6.

Yanaihara A, Otsuka Y, Iwasaki S, Koide K, Aida T, Okai T. Comparison in gene expression of secretory human endometrium using laser microdissection. Reprod Biol Endocrinol. 2004;2:66. doi: 10.1186/1477-7827-2-66.

Ye S. Influence of matrix metalloproteinase genotype on cardiovascular disease susceptibility and outcome. Cardiovasc Res 2006;69: 636 - 645

Yilmaz B, Sucak A, Kilic S, Aksakal O, Aksoy Y, Lortlar N, Sut N, Gungor T. (2010) Metformin regresses endometriotic implants in rats by improving implant levels of superoxide dismutase, vascular endothelial growth factor, tissue inhibitor of metalloproteinase-2, and matrix metalloproteinase-9. Am J Obstet Gynecol.202(4):368.e1-8.

Yoshioka H, Harada T, Iwabe T, Nagano Y, Taniguchi F, Tanikawa M, et al. Menstrual cyclespecific inhibition of the proliferation of endometrial stromal cells by interleukin 6 and its soluble receptor. Am J Obstet Gynecol 1999;180:1088 -94

Zeyneloglu HB, Senturk LM, Seli E, Bahtiyar OM, Olive DL, Arici A. The peritoneal fluid levels of interleukin-12 in women with endometriosis.Am J Reprod Immunol. 1998;39:152- 6 
Zhang X, Nothnick WB. The role and regulation of the uterine matrix metalloproteinase system in menstruating and non-menstruating species. Front Biosci. 2005;10:353366. doi: 10.2741/1533.

Zhao Y, Nichols JE, Bulun SE, Mendelson CR, Simpson ER. Aromatase P450 gene expression in human adipose tissue: role of a Jak/STAT pathway in regulation of the adiposespecific promoter. J Biol Chem 1995;270:16449 -57.

Zhao Z, Nyholt DR, Thomas S, et al (2008) Polymorphisms in the vascular endothelial growth factor gene and the risk of familial endometriosis. Molecular human reproduction 14 (9):531-538. 


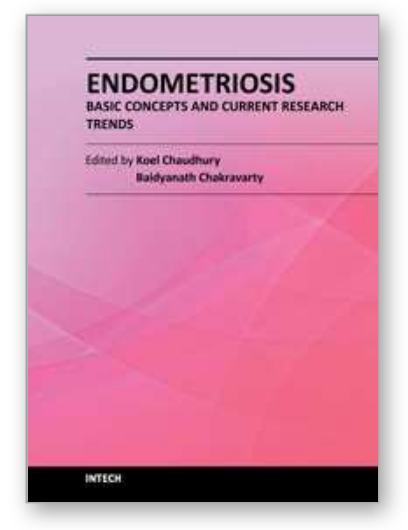

\author{
Endometriosis - Basic Concepts and Current Research Trends \\ Edited by Prof. Koel Chaudhury
}

ISBN 978-953-51-0524-4

Hard cover, 490 pages

Publisher InTech

Published online 09, May, 2012

Published in print edition May, 2012

This book provides an insight into the emerging trends in pathogenesis, diagnosis and management of endometriosis. Key features of the book include overviews of endometriosis; endometrial angiogenesis, stem cells involvement, immunological and hormonal aspects related to the disease pathogenesis; recent research reports on infertility, endometrial receptivity, ovarian cancer and altered gene expression associated with endometriosis; various predictive markers, and imaging modalities including MRI and ultrasound for efficient diagnosis; as well as current non-hormonal and hormonal treatment strategies This book is expected to be a valuable resource for clinicians, scientists and students who would like to have an improved understanding of endometriosis and also appreciate recent research trends associated with this disease.

\title{
How to reference
}

In order to correctly reference this scholarly work, feel free to copy and paste the following:

P. G. Artini, M. Ruggiero, F. Papini, G. Simi, V. Cela and A. R. Genazzani (2012). Endometriosis and Angiogenic Factors, Endometriosis - Basic Concepts and Current Research Trends, Prof. Koel Chaudhury (Ed.), ISBN: 978-953-51-0524-4, InTech, Available from: http://www.intechopen.com/books/endometriosisbasic-concepts-and-current-research-trends/endometriosis-and-angiogenetic-factors

\section{INTECH}

open science | open minds

\author{
InTech Europe \\ University Campus STeP Ri \\ Slavka Krautzeka 83/A \\ 51000 Rijeka, Croatia \\ Phone: +385 (51) 770447 \\ Fax: +385 (51) 686166 \\ www.intechopen.com
}

\author{
InTech China \\ Unit 405, Office Block, Hotel Equatorial Shanghai \\ No.65, Yan An Road (West), Shanghai, 200040, China \\ 中国上海市延安西路65号上海国际贵都大饭店办公楼405单元 \\ Phone: +86-21-62489820 \\ Fax: +86-21-62489821
}


(C) 2012 The Author(s). Licensee IntechOpen. This is an open access article distributed under the terms of the Creative Commons Attribution 3.0 License, which permits unrestricted use, distribution, and reproduction in any medium, provided the original work is properly cited. 